\title{
AMBIGUITAS PERATURAN DAERAH KABUPATEN TANAH DATAR TENTANG PAJAK DAERAH PERSPEKTIF SIYASAH DUSTURIYAH
}

\author{
Hibatul Wafi ${ }^{1}$, Elsy Renie ${ }^{2}$ \\ ${ }^{1}$ Institut Agama Islam Negeri Batusangkar \\ e-mail: hibatulwafi551997@gmail.com \\ 2Institut Agama Islam Negeri Batusangkar \\ e-mail: elsyrenie@iainbatusangkar.ac.id
}

\begin{abstract}
The focus of the research is how ambiguity is in the Tanah Datar Regency Regional Regulation Number 1 of 2018 concerning the Second Amendment to the Tanab Datar Regency Regional Regulation Number 6 of 2011 concerning Regional Taxes. The purpose of this paper is to explain, analyze whether ambiguity occurs in article 43 paragraph 1, article 44 paragraph 1, article 65 paragraph 4 letter $b$ ambiguity in the Tanah Datar Regency Regulation Number 6 of 2011 concerning Regional Taxes as Amended by the Regency Regional Regulation Tanab Datar Number 1 of 2018 concerning the Second Amendment to the Regional Regulation of Tanah Datar Regency Number 6 of 2011 concerning Regional Taxes and to find out how to review article 43 paragraph 1, article 44 paragraph 1, article 65 paragraph 4 letter $b$ Regional Regulation of Tanah Datar Regency Number 6 of 2011 concerning Regional Taxes as Amended by Regional Regulation of Tanah Datar Regency Number 1 of 2018 concerning the Second Amendment to Regional Regulation of Tanah Datar Regency Number 6 of 2011 concerning Regional Taxes in the Perspective of Siyasah Dusturiyah on the Establishment of Good Legislations in the review of Siyasah Dusturiah .
\end{abstract}

Keywords: Dusturiyah Law, Ambiguity, Siyasah Duturiyah.

\section{PENDAHULUAN}

Al-Qur'an, As-Sunnah, Undang-Undang Dasar Republik Indonesia Tahun 1945 dan Peraturan Perundang-Undangan merupakan landasan yang prinsipil dan wajib diamalkan oleh setiap warga negara. Untuk merumuskan dan melaksanakan kebijakankebijakan di segala bidang kehidupan, khususnya bidang hokum dilaksanakan oleh unsur pemerintah. Umat Islam pada khususnya dan bangsa Indonesia pada umumnya wajib mengikuti petunjuk Tuhan Yang Maha Esa, karena kita semua wajib mengikuti perintah Allah SWT dan Rasul-Nya serta pemerintah (Peraturan Perundang-undangan). Perintah ini disebutkan dalam surat An-Nisa' ayat (59) yang artinya: Hai orang-orang yang beriman, taatilah Allah dan taatilah Rasul (Nya), dan ulil amri di antara kamu. kemudian jika kamu berlainan Pendapat tentang sesuatu, Maka kembalikanlah ia kepada Allah (Al Quran) dan Rasul (sunnahnya), jika kamu benar-benar beriman kepada Allah dan hari kemudian. yang demikian itu lebihutama (bagimu) dan lebih baik akibatnya. (QS An-Nisa' ayat 59)

Ayat ini memerintahkan kita untuk taat kepada Allah SWT, taat kepada Rasulullah dan taat kepada penguasa. Oleh karena itu, kita wajib mengamalkan peraturan Allah, peraturan Rasul-Nya dan peraturan yang dibuat oleh pemimpin ataupenguasa, dalam hal ini pemerintah berupa Peraturan Perundang-Undangan atau Qanun, baik yang dibuat oleh pemerintah pusat maupun yang dibuat oleh pemerintah daerah. (Afrialdi, 2018: 1) 
Sebagai negara yang berlandaskan yuridis pada Undang-Undang Dasar 1945, segala aspek kehidupan dalam bidang kemasyarakatan kebangsaan dan keanekaragaman termasuk pemerintahan harus senantiasa berdasarkan hukum. Sebelumnya, landasan negara hukum Indonesia ditemukan dalam bagian Penjelasan Umum UUD 1945 tentang Sistem Pemerintahan Negara, yaitu sebagai berikut:

1. Indonesia adalah negara yang berdasar atas hukum (Rechsstaat). Negara Indonesia berdasar atas Hukum (Rechsstaat), tidak berdasar atas kekuasaan belaka (Machtsstaat).

2. Sistem Konstitusional yaitu Pemerintah berdasar atas sistem konstitusi (hukum dasar), tidak bersifat absolutisme (kekuasaan yang tidak terbatas).

Undang-Undang adalah suatu produk hukum yang berfungsi sebagai sumber rujukan peraturan hidup di dalam bermasyarakat dan bernegara yang memiliki sifat mengarahkan, mencegah, mengekang, dan memaksa dalam penerapannya. (Syarifin dan Jubaedah, 2012:17). Undang-Undang dapat dilihat dari dua sudut pandang, pertama yaitu Undang-Undang dalam artian formil yaitu keputusan (beslissing) yang dimuat secara tertulis dan diadakan oleh badan kenegaraan yang pada saat ini badan kenegaraan yang dimaksud adalah Presiden bersama DPR, dan yang ke dua Undang-Undang dalam artian materil yaitu suatu peraturan tertulis yang memiliki kekuatan hukum dan diciptakan oleh pihak yang berwenang, baik pihak pusat maupun pihak daerah yang sah. (Purbacaraka, 1993:3)

Penjelasan Peraturan Perundangan-Undangan dapat ditemukan di dalam UndangUndang Nomor 15 Tahun 2019 Tentang Perubahan Atas Undang-Undang Nomor 12 Tahun 2011 Tentang Pembentukan Peraturan Perundang-Undangan Pasal 1 Ayat 2 Tentang Pembentukan Peraturan Perundang-Undang "Peraturan Perundang- Undangan adalah peraturan tertulis yang memuat norma hukum yang mengikat secara umum dan dibentuk atau ditetapkan oleh lembaga negara atau pejabat yang berwenang melalui prosedur yang ditetapkan dalam Peraturan Perundang-undangan". (UU No15 Tahun 2019 Tentang Perubahan Atas UU No 12 Tahun 2011 Tentang Pembentukan Peraturan Perundang-Undangan).

Pembentukan Peraturan Perundang-undangan yang baik dan benar, haruslah merujuk kepada landasan pembentukan Peraturan Perundang-Undangan, yang di dalamnya harus memuat landasan yuridis. Setiap produk hukum, harus mempunyai dasar berlaku secara yuridis. Dasar yuridis ini sangat penting dalam pembuatan peraturan Perundang-undangan (termasuk Peraturan Derah), yang akan menunjukan keharusan adanya kewenangan dari pembuat produk-produk hukum. Setiap produkproduk hukum harus dibuat oleh pejabat yang berwenang. Kalau tidak, produk-produk hukum itu batal demi hukum atau dianggap tidak pernah ada dan segala akibatnya batal demi hukum, keharusan adanya kesesuaian bentuk atau jenis produk-produk hukum dengan materi yang diatur, terutama kalau diperintahkan oleh peraturan PerundangUndangan yang tingkatannya lebih tinggi atau sederajat. Ketidaksesuaian bentuk atau jenis dapat menjadi alasan untuk membatalkan atau dapat dibatalkan (vernietigbaar) produk hukum tersebut, keharusan mengikuti tata cara tertentu, apabila tata cara tertentu tidak diikuti, maka produk-produk hukum tersebut belum mempunyai kekuatan hukum mengikat dan dapat dibatalkan demi hukum, keharusan tidak bertentangan dengan 
Peraturan Perundang-Undangan yang lebih tinggi tingkatanya, Produk-produk hukum yang dibuat untuk umum dapat diterima oleh masyarakat secara wajar bahkan spontan.

Dalam Fiqh Siyasah, prinsip pembentukan Peraturan Perundang-Undangan adalah menjamin hak asasi manusia setiap anggota masyarakat dan persamaan kedudukan di mata hukum, tanpa membeda-bedakan strafikasi sosial, kekayaan, pendidikan, agama dengan Peraturan Perundang-Undangangan yang memenuhi asas kepastian hukum.

Sebagai negara yang berdasarkan pada Undang-Undang Dasar 1945, segala aspek kehidupan dalam bidang kemasyarakatan kebangsaan dan keanekaragaman termasuk pemerintahan harus senantiasa berdasarkan hukum sebagaimana yang diatur di dalam Undang-Undang Negara Republik Indonesia Tahun 1945 Pasal 1 Ayat 3 "Negara Indonesia adalah negara hukum", hal ini sesuai dengan asas hukum yaitu suatu hukum harus memiliki asas kepastian hukum. (Undang-Undang Dasar Negara Republik Indonesia Tahun 1945)

Peraturan Daerah Kabupaten Tanah Datar Nomor 6 Tahun 2011 Tentang Pajak Daerah Sebagaimana Telah Diubah Dengan Peraturan Daerah Kabupaten Tanah Datar Nomor 1 Tahun 2018 Tentang Perubahan Kedua Atas Peraturan Daerah Kabupaten Datar Nomor 6 Tahun 2011 Tentang Pajak Daerah memiliki tiga pasal yang berimplikasi multitafsir yaitu, Pertama Pasal 43 Ayat 1 "Objek Pajak Sarang Burung Walet adalah pengambilan dan atau untuk pengusahaan sarang burung walet", Kedua Pasal 44 Ayat 1 "Subjek Pajak Sarang Burung Walet adalah orang pribadi atau badan yang melakukan pengambilan dan atau mengusahakan sarang burung walet.", ketiga Pasal 65 Ayat 4 Huruf h "Pajak Bea Perolehan Hak Atas Tanah dan atau Bangunan".

Ketiga pasal di atas menggunakan kata sambung "dan atau" yang tidak sesuai dengan Undang-Undang Nomor 15 Tahun 2019 Tentang Perubahan Atas UndangUndang Nomor 12 Tahun 2011 Tentang Pembentukan Peraturan Perundang- Undangan Lampiran 1 Nomor 90 "Jika rincian dalam tabulasi dimaksudkan sebagai rincian kumulatif dan alternatif, ditambahkan kata dan/atau yang diletakkan di belakang rincian kedua dari rincian terakhir".

Penulis akan mengkaji apakah kekaburan makna terjadi pada Pasal 43 Ayat 1, Pasal 44 Ayat 1, Pasal 65 Ayat 4 huruf h Peraturan Daerah Kabupaten Tanah Datar Nomor 6 Tahun 2011 Tentang Pajak Daerah Sebagaimana Telah Diubah Dengan Peraturan Daerah Kabupaten Tanah Datar Nomor 1 Tahun 2018 Tentang Perubahan Kedua Atas Peraturan Daerah Kabupaten Tanah Datar Nomor 6 Tahun 2011 Tentang Pajak Daerah.

Berdasarkan fokus penelitian yang penulis paparkan di atas, maka yang menjadi rumusan masalah dalam penelitian ini adalah Apakah kekaburan makna terjadi pada Pasal 43 Ayat 1, Pasal 44 Ayat 1, Pasal 65 Ayat 4 huruf h Peraturan Daerah Kabupaten Tanah Datar Nomor 6 Tahun 2011 Tentang Pajak Daerah Sebagaimana Telah Diubah Dengan Peraturan Daerah Kabupaten Tanah Datar Nomor 1 Tahun 2018 Tentang Perubahan Kedua Atas Peraturan Daerah Kabupaten Tanah Datar Nomor 6 Tahun 2011 Tentang Pajak Daerah dan Bagaimana tinjauan Pasal 43 Ayat1, Pasal 44 Ayat 1, Pasal 65 Ayat 4 huruf h Peraturan Daerah Kabupaten Tanah Datar Nomor 6 Tahun 2011 Tentang Pajak Daerah Sebagaimana Telah Diubah Dengan Peraturan Daerah Kabupaten Tanah Datar Nomor 1 Tahun 2018 Tentang Perubahan Kedua Atas Peraturan Daerah Kabupaten 
Tanah Datar Nomor 6 Tahun 2011 Tentang Pajak Daerah terhadap pembentukan Peraturan Perundang-Undangan yang baik dalam Siyasah Dusturiah.

\section{METODE PENELITIAN}

Penelitian ini menggunakan jenis Penelitian Hukum Normatif. Penelitian Hukum Normatif atau penelitian kepustakaan (Library Research) adalah penelitian yang mengkaji studi dokumen (mengkaji data yang ada), yakni menggunakan berbagai data baik data primer seperti Peraturan Perundang-undangan, keputusan pengadilan, teori hukum, dan data sekunder seperti pendapat sarjana, hasil penelitian. (Soekanto dan Soerjono, 2009:1314) Dengan demikian penelitian ini akan menggambarkan masalah hukum yang terjadi antara Teori yang dicita-citakan dengan hasil yang dicapai. Penulis akan menggambarkan apakah terjadi kekaburan makna pada Pasal 43 Ayat 1, Pasal 44 Ayat 1, Pasal 65 Ayat 4 huruf h Peraturan Daerah Kabupaten Tanah Datar Nomor 6 Tahun 2011 Tentang Pajak Daerah Sebagaimana Telah Diubah Dengan Peraturan Daerah Kabupaten Tanah Datar Nomor 1 Tahun 2018 Tentang Perubahan Kedua Atas Peraturan Daerah Kabupaten Tanah Datar Nomor 6 Tahun 2011 Tentang Pajak Daerah, kemudian penulis akan menganalisanya sehingga diperoleh suatu gambaran yang utuh dan menyeluruh tentang permasalahan yang akan diteliti

\section{HASIL DAN PEMBAHASAN}

Implikasi dari kekaburan makna suatu Undang-undang adalah menimbulkan ketidakpastian hukum dalam pelaksanaannya, Terhadap penggunaan kata dan/atau yang tidak sesuai dengan pedoman pembentukan peraturan Perundang-undangan yang diatur oleh Undang-Undang No 15 Tahun 2019 Tentang Perubahan Atas UU No 12 Tahun 2011 Tentang Pembentukan Peraturan Perundang-Undangan. Kriteria-kriteria penggunaan kata sambung tersebut menjadi hal penting yang harus dicermati agar tidak terjadi perbedaan penafsiran dalam pelaksanaannya, sehingga dapat dibedakan dengan jelas antara jenis kata sambung yang ada. Norma yang kabur, multi tafsir dan ambigu mengakibatkan tidak adanya kepastian hukum, sementara salah satu tujuan hukum adalah untuk mewujudkan kepastian hukum. Makna kepastian hukum mempunyai dua pengertian, yaitu adanya aturan yang bersifat umum membuat individu mengetahui perbuatan apa yang boleh atau yang tidak boleh dilakukan; dan adanya keamanan hukum bagi individu dari kesewenang-wenangan pemerintah. (Mahmud, 1999: 37).

Setidak-tidaknya ada dua aspek yang diharmonisasikan pada waktu menyusun peraturan perundang-undangan, yaitu yang berkaitan dengan aspek konsepsi materi muatan dan aspek teknik penyusunan peraturan perundang- undangan. Dari tujuh konsepsi pengharmonisan pembuatan peraturan perundang-undangan yaitu Pancasila, Undang- Undang Dasar, Asas Materi Muatan, Perundang-Undangan lain, Konvensi/perjanjian internasional, Putusan MK/Putusan MA, Teori Hukum terdapat dua aspek yang tidak terharmonisasikan yaitu Pengharmonisasian dengan PerundangUndangan lain dan Pengharmonisasian dengan Teori Hukum, ini terbukti dari temuan di lapangan terhadap pertentangan Peraturan Daerah pasal 43 ayat 1, pasal 44 ayat 1, pasal 
65 ayat 4 huruf h Peraturan Daerah Kabupaten Tanah Datar Nomor 6 Tahun 2011 Tentang Pajak Daerah Sebagaimana Telah Diubah Dengan Peraturan Daerah Kabupaten Tanah Datar Nomor 1 Tahun 2018 Tentang Perubahan Kedua Atas Peraturan Daerah Kabupaten Datar Nomor 6 Tahun 2011 Tentang Pajak Daerah dengan Undang-Undang Nomor 15 Tahun 2019 Tentang Perubahan Atas Undnag-Undang Nomor 12 Tahun 2011 Tentang Pembentukan Peraturan Perundang-Undangan, dan untuk pengharmonisasian dengan teori hukum itu tidak terjadi karena dengan terjadinya pertentangan diantara PerundangUndangan itu sudahmembuktikan bahwa teori hukum tercapai.

Dari pemaparan di atas, maka analisa penulis adalah salah satu dari tiga nilai dasar hukum yaitu Kepastian Hukum yang erat kaitannya dengan Harmonisasi Undang-Undang. Pasal 43 Ayat 1, Pasal 44 Ayat 1, Pasal 65 Ayat 4 Huruf h Peraturan Daerah Kabupaten Tanah Datar Nomor 6 Tahun 2011 Tentang Pajak Daerah Sebagaimana Telah Diubah Dengan Peraturan Daerah Kabupaten Tanah Datar Nomor 1 Tahun 2018 Tentang Perubahan Kedua Atas Peraturan Daerah Kabupaten Datar Nomor 6 Tahun 2011 Tentang Pajak Daerah merupakan bentuk ketidak timbulannya Kepastian Hukum yang merupakan nilai hukum dasar. Hal ini juga dicerminkan dengan ketidak adaannya Naskah Akademik Peraturan Daerah Kabupaten Tanah Datar Nomor 1 Tahun 2018 Tentang Perubahan Kedua Atas Peraturan Daerah Kabupaten Tanah Datar Nomor 6 Tahun 2011 Tentang Pajak Daerah. (Hasil Wawancara, 12 Juni 2020, Plt. KABAGHukum Sekretariat Daerah Kabupaten Tanah Datar). Nilai selanjutnya dalam teori nilai dasar hukum yaitu nilai kemanfaatan atau utilitarian, suatu undang-undang diciptakan untuk memenuhi dan menjawab tantangan problematika yang muncul dalam suatu wilayah hukum dalam artian bermanfaat atau memiliki peran, dalam analisis ini ketiga pasal di atas tidak mencerminkan Undang-Undang yang memiliki kemanfaatan, bahkan dengan terjadinya kekaburan makna pada suatu undang-undang akan menimbulkan kecacatan hukum yang berujung padapencabutan Peraturan Daerah terkait.

Kemudian dalam konteks pertentangan dengan undang-undang lain, penulis menganalisa bahwasanya Pasal 43 Ayat 1, Pasal 44 Ayat 1, Pasal 65 Ayat 4 Huruf h Peraturan Daerah Kabupaten Tanah Datar Nomor 1 Tahun 2018 Tentang Perubahan Kedua Atas Peraturan Daerah Kabupaten Tanah Datar Nomor 6 Tahun 2011 Tentang Pajak Daerah meggunakan kata sambung dan/atau yang tidak seperti dijelaskan di ketiga pilihan di atas. Sehingga jelas penggunaan kata "dan/atau" pada ketiga pasal Perda Kabupaten Tanah Datar di atas tidak sesuai dengan Lampiran II UU No 15 Tahun 2019 Tentang Perubahan Atas UU No 12 Tahun 2011 Tentang Pembentukan Peraturan Perundang-Undangan, kurangnya ketelitian dalam pembentukan suatu peraturan perundang-undangan merupakan faktor utama hal seperti ini terjadi, keberadaan Naskah Akademik memiliki arti penting dalam pengkajian suatu draft perundang-undangan mulai dari nilai-nilai yang diperjuangkan hingga draft pasal-pasal yang telah disiapkan baik itu draft yang diusulkan oleh Pemerintah Daerah maupun draft yang diusulkan oleh Dewan Perwakilan Rakyat Daerah.

Dari uraian di atas dapat disimpulkan dengan terjadinya ketidak harmonisan Pasal 43 Ayat 1, Pasal 44 Ayat 1, Pasal 65 Ayat 4 Huruf h Peraturan Daerah Kabupaten Tanah Datar Nomor 6 Tahun 2011 Tentang Pajak Daerah Sebagaimana Telah Diubah Dengan Peraturan Daerah Kabupaten Tanah Datar Nomor 1 Tahun 2018 Tentang Perubahan 
Kedua Atas Peraturan Daerah Kabupaten Datar Nomor 6 Tahun 2011 Tentang Pajak dengan Undang-Undang No 15 Tahun 2019 Tentang Perubahan Atas UU No 12 Tahun 2011 Tentang Pembentukan Peraturan Perundang-Undangan maka akan terjadi kekaburan makna pada ketiga pasal Peraturan Daerah Kabupaten Tanah Datar. Disamping ketidak harmonisan antara kedua Undang-Undang di atas, ketiga pasal Peraturan Daerah Kabupaten Tanah Datar tidak menggambarkan nilai-nilai dasar hukum yang dikemukakan oleh Gustav Radbruch yang berarti terjadinya kecacatan hukum pada Perda Kabupaten Tanah Datar Nomor 1 Tahun 2018 Tentang Perubahan Kedua Atas Peraturan Daerah Kabupaten Tanah Datar Nomor 6 Tahun2011 Tentang Pajak Daerah.

\section{Siyasah Dusturiyah}

Siyasah dusturiyah adalah bagian fiqh siyasah yang membahas masalah perundangundangan negara. Dalam hal ini juga dibahas antara lain konsep- konsep konstitusi (undang-undang dasar negara dan sejarah lahirnya perundang- undangan dalam suatu negara), legislasi (bagaimana cara perumusan undang-undang), lembaga demokrasi dan syura yang merupakan pilar penting dalam perundang-undangan tersebut. Di samping itu, kajian ini juga membahas konsep negara hukum dalam siyasah dan hubungan timbal balik antara pemerintah dan warga negara serta hak-hak warga negara yang wajib dilindungi. (Iqbal, 2014: 177).

Dalam kajian siyasah dusturiyah, legislasi merupakan kekuasaan pemerintah Islam dalam membuat dan menetapkan hukum yang akan diberlakukan dan dilaksanakan oleh masyarakatnya berdasarkan ketentuan yang telah diturunkan Allah dalam syariat Islam. Pada masa Nabi Muhammad, otoritas yang membuat tasyri' (hukum) adalah Allah. Allah menurunkan ayat-ayat al- Qur'an secara bertahap selama lebih kurang 23 tahun. Adakalanya ayat tersebut diturunkan untuk menjawab suatu pertanyaan, adakalanya pula untuk menanggapi suatu perubahan atau permasalahan yang terjadi dalam masyarakat. Nabi Muhammad juga berperan sebagai penjelas terhadap ayat-ayat al-Qur'an yang masih bersifat global dan umum. Legislasi besar-besaran dilakukan pada massa pemerintahan Usmani (1300-1924). Pada masa ini, hukum yang dipakai dalam masyarakat bukan hanya fiqh, melainkan juga keputusan khalifah atau sultan terhadap sengketa atau perselisihan yang terjadi diantara anggota masyarakat. Selain itu, ada juga keputusan yang diambil dalam rapat majelis legislatif sebagai al-sulthah al-tasyri'iyah dan disetujui oleh khalifah. Bentuk pertama disebut idarah saniyah, sedangkan yang kedua dinamakan dengan qanun. Puncak kemajuan qanun ini tejadi pada masa Khalifah Sulaiman I (15201566 M). (Iqbal, 2014: 177).

Dengan demikian unsur-unsur legislasi dalam Islam meliputi:

a. Pemerintah sebagai pemegang kekuasaan untuk menetapkan hukum yang akan diberlakukan dalam masyarakat Islam;

b. Masyarakat Islam yang akan melaksanakanya;

c. Isi peraturan atau hukum itu sendiri yang harus sesuai dengan nilai - nilai dasar syariat Islam.

Islam juga memiliki pola pembentukan Peraturan Perundang-Undangan yang sistematis, dengan pembagian kekuasaan yang mempermudah pelaksanaan tugas dan fungsi negara. Figh Siyasah memiliki bagian kusus yang mengatur pembentukan peraturan, yaitu adalah Al-sulthah al-tasyri"iyah yang merupakan kekuasaan legislati. 
Hukum yang dibuat melalui prosedur ini lebih bersifat alami daripada yang dibuat oleh aliran-aliran tradisional, sebagaimana yang pernah berkembang dalam sejarah islam. Hukum yang dibuat terakhir ini merupakan karya penafsir individual yang tidak lepas dari subjektivitas mazhab. Adapun hukum yang dibuat oleh lembaga legislatif merupakan pemikiran kolektif yang sudah disaring dan didiskusikan secara lebih mendalam. Karenanya, pemikiran individu tidak mungkin bisa mengimbangi pemikiran kolektif yang sudah teruji. Dari pemikiran di atas, Rahman menyimpulkan bahwa sumber fisik semua wewenang dan kekuasaan adalah umat islam itu sendiri. Kekuasaan itu kemungkinan dilimpahkan kepada dewan legislatif untuk membuat undang- undang yang sesuai dengan syariat islam. Pembentukan lembaga Ahlu al-halli wal Aqdi perlu dalam pemerintahan Islam, dalam rangka memperjuangkan nilai-nilai kemaslahatan di dalam Peraturan Perundang-Undangan yang dibuat. Mengingat banyak permasalahan kenegaraan yang harus diputuskan secara bijak dan pandangan yang tajam, sehingga mampu menciptakan kemaslahatan umat Islam yang nyata. (Nurkholbi, 2019: 47)

Dengan uraian teori di atas maka analisis penulis bahwasanya suatu Peraturan Perundang-Undangan dalam konteks siyasah tasyri'iyah di ciptakan melalui proses yang memperhatikan ketertiban, kemaslahatan dan sistematis ini dibuktikannya dengan adanya bagian pembentukan peraturan didalam konsep Figh Siyasah "Al-sulthah altasyri'iyah" yang merupakan bagian kusus yang dibentuk kusus untuk mewenangi pembentukan hukum-hukum dengan keutamaan mengeluarkan Peraturan PerundangUndangan yang bernilai maslahat oleh umat. Di dalam teori ushul fiqh pengambilan keputusan atau ijma' didasari dengan kaidah-kaidah ushul dasar atau dalil, Muhammad Abu Zahra menggambarkan definisi maslahah adalah segala kemanfaatan yang sejalan dengan tujuan-tujuan syari' (dalam mensyari'atkan hukum Islam) dan kepadanya tidak ada dalil khusus yang menunjukkan tentang diakuinya atau tidaknya yang mana pembentukan peraturan perundang-undangan merupakan perilaku dengan tujuan syari'.

\section{KESIMPULAN}

Berdasarkan uraian yang telah penulis kemukakan pada bab-bab sebelumnya dan mengerucut pada inti dari masalah yang penulis kaji dengan judul Kekaburan Makna Pada Peraturan Daerah Kabupaten Tanah Datar Nomor 6 Tahun 2011 Tentang Pajak Daerah Sebagaimana Telah Diubah Dengan Peraturan Daerah Kabupaten Tanah Datar Nomor 1 Tahun 2018 Tentang Perubahan Kedua Atas Peraturan Daerah Kabupaten Tanah Datar Nomor 6 Tahun 2011 Tentang Pajak Daerah Dalam Perspektif Siyasah Dusturiyah maka dapat disimpulkan sebagai berikut pertama Bahwa pasal 43 ayat 1, pasal 44 ayat 1, pasal 65 ayat 4 huruf h Peraturan Daerah Kabupaten Tanah Datar Nomor 6 Tahun 2011 Tentang Pajak Daerah Sebagaimana Telah Diubah Dengan Peraturan Daerah Kabupaten Tanah Datar Nomor 1 Tahun 2018 Tentang Perubahan Kedua Atas Peraturan Daerah Kabupaten Tanah Datar Nomor 6 Tahun 2011 Tentang Pajak Daerah tidak merujuk kepada Lampiran II No. 90 Undang-Undang Nomor 15 Tahun 2019 Tentang Perubahan Atas Undang-UndangNomor 12 Tahun 2011 Tentang Pembentukan Peraturan PerundangUndangan ini dibuktikan dengan ketidak sesuaian penggunaan kata sambung dan atau yang seharusnya disertai dengan garis miring (/) sehingga menimbulkan kekaburan 
makna pada pasal 43 ayat 1, pasal 44 ayat 1, pasal 65 ayat 4 huruf h kedua Bahwa Pasal 43

Ayat 1, Pasal 44 Ayat 1, Pasal 65 Ayat 4 huruf h Peraturan Daerah Kabupaten Tanah Datar Nomor 6 Tahun 2011 Tentang Pajak Daerah Sebagaimana Telah Diubah Dengan Peraturan Daerah Kabupaten Tanah Datar Nomor 1 Tahun 2018 Tentang Perubahan Kedua Atas Peraturan Daerah Kabupaten Tanah Datar Nomor 6 Tahun 2011 Tentang Pajak Daerah tidak mencerminkan sistem Pembentukan Peraturan Perundang-Undangan yang baik dalam kajian Siyasah Dusturiyah yang memperhatikan kemaslahatan, hal ini terbukti dengan pertama ketidak beradaannya Naskah Akademik yeng merupakan landasan nilai-nilai yang diperjuangkan pada suatu undang-undang, kedua dengan terjadinya disharmonisasi antara UU No. 15 Tahun 2019 Tentang Perubahan Atas UU No. 12 Tahun 2011 Tentang Pembentukan Peraturan Perundang-Undangan dengan PERDA Tanah Datar No. 1 Tahun 2018Tentang Perubahan Kedua Atas PERDA Kabupaten Tanah Datar No. 6 Tahun 2011 Tentang Pajak Daerah membuktikan timbulnya ke mudharatan di dalam Peratuan ini.

\section{DAFTAR PUSTAKA}

Afrialdi, M. (2018). Implementasi Pasal 5 Ayat 2 Undang-Undang Nomor 12 Tahun 2011 Tentang Pembentukan Peraturan Perundang-Undangan. Skripsi. Jurusan Hukum Tata Negara IAIN Batusangkar. Batusangkar.

BPS Kabupaten Tanah Datar, https://sp2010.bps.go.id/index.php/site?id=1305000000 \&wilayah=Tanah-Data, diakses pada 5 Mei 2020.

Djazuli, A. (2004). Implementasi Kemaslahatan Umat dalam Rambu-rambu Syari'ah. Jakarta: Kencana.

Fadli, M. (2018).Pembentukan Undang-Undang Yang Mengikuti Perkembangan Masyarakat. Bandung: Pustaka Setia.

Hamzah, A. (2005). Kamus Hukum. Jakarta: Ghalia Indonesia.

Hasaballah, A. (1986). Ushul at-Tasyri" al-Islami. Mesir: Dar al-Maeearif. Indrati, Maria Farida. (2007). Ilmu Perundang-Undangan. Bandung: Pt. Kashisih.

Iqbal, M. (2014). Fiqh Siyasah: Konstektualisasi Doktrin Politik Islam.

Jakarta: Prenadamedia Group.

Mahmud, P. (1999). Penelitian Hukum. Jakarta: Kencana Prenada Media.

Manullang, E. F. (2016). Legisme, Legalitas, dan Kepastian Hukum. Jakarta: Kharisma Putra Utama.

Martitah, A. H. (2008). Hukum Tata Negara. Semarang: Perpustakaan Pribadi Slamet SMartitah.

Ni'matul, H. (2010). Ilmu Negara. Jakarta: Raja Grafindo Persada.

Nurkholbi, D. (2019). Analisis Fikih Siyasah Dusturiyah Terhadap Proses Pembentukan Peraturan Perundang-Undangan Di Indonesia. Tesis. Jurusan Hukum Tata Negara Pascasarjana Universitas Islam Negeri Sunan Ampel Surabaya.Surabaya.

Prayogo, T (2016). Penerapan Asas Kepastian Hukum Dalam Peraturan Mahkamah Agung Nomor 1 Tahun 2011 Tentang Hak Uji Materiil Dan Dalam Peraturan 
Mahkamah Konstitusi Nomor 06/Pmk/2005 Tentang Pedoman Beracara Dalam Pengujian Undang-Undang. Jurnal Legislasi Indonesia. 13 (2): 193-194.

Purbacaraka, P. D. (1993). Perundang-Undangan dan Yurisprudensi. Bandung: PT Citra Aditya Bakti.

Rusli, H. (2006). Metode Penelitian Hukum Normatif: Bagaimana?. Law Review Fakultas Hukum Universitas Pelita Harapan. 5(1): 47-49.

S, M. F. (2007). Ilmu Perundang-Undangan (jenis, fungsi, dan materi muatan). Yogyakarta: Kanisius.

Sarwano. (2006). Metode Penelitian Kuantitatif \& Kulaitatif. Yogyakarta: Graha Ilmu.

Soekanto, S. \& S. M. (2009). Penelitian Hukum Normatif. Jakarta: Raja Grafindo Persada.

Soekanto. (1986). Pengantar Penelitian Hukum. Jakarta: UI Press.

Sova, S. (2013). Tiga Nilai Dasar Hukum Menurut Gustav Radbruch. Skripsi. Jurusan Hukum.

Universitas Diponegoro. Semarang.

Sugiyono. (2013). Metode Penelitian Kuatitatif, Kualitatif, dan REDi. Bandung:Alfabeta.

Syamsuddin, A. (2015). Proses E Teknik Penyusunan Undang-Undang. Jakarta:Sinar Grafika.

Syarifin, P \& Jubaedah. (2012). Ilmu Perundang-Undangan. Bandung: Pustaka Setia.

Undang-Undang Dasar Negara Republik Indonesia Tahun 1945.

Undang-Undang Nomor 15 Tahun 2019 Tentang Perubahan Atas Undang-Undang Nomor 12 Tahun 2011 Tentang Pembentukan Peraturan Perundang-Undangan.

Yuliandri. (2013). Asas-Asas Pembentukan Peraturan Perundang-Undangan Yang Baik. Jakarta: Rajawali Pers.

Zahra, A. (2006). al-Imam. Ushul al-Fiqhi. al-Qahirah. Dar al Fikr al- Arabi 